\title{
EFFECT OF GOVERNMENT ROLE, SOCIAL CAPITAL AND ORIENTATION OF SOCIAL ENTREPRENEURSHIP ON PERFORMANCE OF VILLAGE CREDIT INSTITUTION IN BALI PROVINCE, INDONESIA
}

\author{
Mashudi*, Sudirman I W., Murjana Yasa I G.W., Saskara I A N. \\ Economics and Business Faculty, University of Udayana, Bali, Indonesia \\ *E-mail: hudibali@gmail.com
}

\begin{abstract}
Village Credit Institutions (LPD) in the province of Bali has a huge role for Bali's economic development. In this case, the contribution of the LPD is as a provider of employment, a pillar of Balinese economic activity.LPD, in addition to being a village-based economic empowerment business institution, is recognized as an institution where the community works in developing the idea of social entrepreneurship. The Regional Government has carried out various LPD empowerment programs, but the optimization of social capital and social entrepreneurship is not optimal. This study aims to improve the role of government, social capital, social entrepreneurship, orientation in improving LPD performance, with social entrepreneurship orientation as a mediating variable in improving LPD performance. This study surveyed 95 LPD administrators, and by using data analysis techniques guided by the Smart PLS-30 software, found: The role of the Government and Social Capital significantly influences the Social Entrepreneurship Orientation in LPDs; The Role of Government, Social Capital and Social Entrepreneurial Orientation significantly influenced LPD performance. The Orientation of Social Entrepreneurship partially mediates the role of the Government and Social Capital on LPD Performance. This study found the role of government, social capital and social entrepreneurship oriented influence the improvement of LPD performance. However, the Social Entrepreneurship Orientation is only partially mediated by the Role of the Government and Social Capital in improving LPD performance. This study recommends that maximize the role of government, optimize social capital and social entrepreneurship orientation to improve LPD performance.
\end{abstract}

\section{KEY WORDS}

Government role, social capital, social entrepreneurship, orientation, LPD performance.

At present in Indonesia the type of microfinance is very diverse. Formal microfinance is part of the banking industry such as Teras BRI (Mi Kro BRI unit), Danamon Simpan Pinjam, the Bank Mandiri Micro-banking Unit, and the Rural Bank (BPR). And part of the non-banks such as Credit Unions (KSP), Rural Credit Agency (BKD), the District Credit Agency (BKK), and Village Credit Institutions (LPD). The existence of the microfinance system has not touched the entire community and micro-entrepreneurs.

The Village Credit Institution or LPD in Bali is a financial institution owned by a traditional village, the same as the LPN in West Sumatra. This institution was established in 1985, and in 2016 the number reached 1,443 LPDs. Village Credit Institutions in Bali are the most successful microfinance institutions in Indonesia. The success of this program is due to the full support of the Bali Provincial Government and the strength of the indigenous peoples in Bali. The history of the LPD itself began in 1985, with the launch of a pilot project with a period of three years, from March 1985 to March 1988. At that time as a first step, the Bali Provincial Government established 161 LPDs with an initial capital of IDR 2 million. In 1986 the provincial government issued regulations relating to villages which gave customary villages the authority to manage assets through their own organizations. Bank Indonesia's efforts to encourage LPDs to turn into BPRs were denied by the people in Bali, besides that $\mathrm{BI}$ also considered the large number of LPDs that had to be monitored, so that BI finally gave its approval by deciding that the LPD was a non - bank financial institution specifically operating in Bali. In Act No. 1 of 2013 concerning MFIs, the existence of the LPD is 
recognized as financial institution, so that it is not included as an MFI regulated in the regulation. At present the regulations governing LPD are Bali Provincial Regulation No. 4 of 2012. LPD management is fully carried out by traditional villages, with guidance and supervision carried out by the provincial government and BPD.

In a village area in Bali Province there are two different government systems and sometimes overlapping. The formal government in the structure is the official village headed by a village head and traditional village headed by a custom "bendesa" assisted by "prajuru". Each type of device has its own this government, which "bendesa" custom selected by "Paruman" village which is a village-level meetings. Bendesa as a chairman in managing the LPD usually appoints a LPD head or manager through village meetings, with an organization separate from the management of "bendesa", but directly responsible to the adat paruman. "B Endesa" serves as an internal supervisor in the management of LPD. LPD deposits and loans are only permitted to traditional village members. The amount of deposits both savings and time deposits is not limited, but usually the loan amount is adjusted to LPD liquidity and collateral or collateral. Funds raised by the LPD may be derived from another financial institution but the number is limited. The LPD since it was initiated in November 1984 by the Governor of Bali, which at that time was held by Ida Bagus Mantra (Alm), the LPD has assumed a function to encourage the economic development of the community through targeted savings and effective channeling of capital. Besides that, LPDs are also expected to eradicate debt bondage systems and black pledges which at that time often occur in the community. Other functions also carried by the LPD are creating equity and employment opportunities for rural communities, both those who usually work directly at LPDs and those that can be accommodated by businesses. Productive communities funded by LPDs, creating purchasing power, and expediting payment and exchange traffic in villages are also the main tasks of the LPD.

The existence of LPD as one of the microfinance institutions has the following businesses: 1) Receive / collect funds from the village Krama in the form of savings and deposits. 2) Providing loans only to Krama villages. 3) Receive loans from financial institutions to a maximum of 100 percent of the total capital, including reserves and retained earnings, except for other limitations in the amount of loans or capital support / assistance. 3) Save excess liquidity with BPD Bali in return for competitive interest and adequate services.

LPD is a business entity engaged in the economy has the purpose of gaining profit, where profits are allocated to: capital of 60 percent, the village development fund customary 20 percent, production services 10 percent, the fund coaching, supervision and protection of 5 percent, and social funds as much as 5 percent.

The description of the number of LPDs, assets and profits of the Village Credit Institution in Bali in 2016 is fully presented in the table 1.

Based on the table above, it can be seen from the number of LPDs owned by regencies in Bali Province that the largest number of LPDs in Tabanan district were 307 LPDs while LPDs in Denpasar City were only 35 LPDs. LPD from the asset side, Badung regency has the highest total assets of 4.2 trillion later by 3.3 trillion Gianyar regency, Buleleng regency and Denpasar, each of 1.8 trillion and 1.6 trillion in assets, while the lowest in the county LPD amounted Jembaran 0.480 trillion. From the average profit obtained by LPDs in each district, the highest profit was obtained by LPDs in Denpasar City by an average of 2 billion followed by Badung regency of 1.1 billion, Buleleng regency district at 384,798 million, Gianyar regency at 382,180 million, Jembrana Regency amounted to 307,190 million, Klungkung regency amounted to 262,111 million, Bangli regency amounted to 215,224 million, Karangasem regency amounted to 184,888 million and the lowest was Tabanan regency at 149,119 million.

From this description, it is explained that LPDs in Tabanan regency, Karangasem regency and Bangli district are still very low profit compared to LPDs in other districts. Whereas in these 3 districts, there were 656 LPD units, each in Tabanan district, 307 LPD, Karangansem district, 190 LPD and Bangli regency, 159 LPDs, or about $45.77 \%$ of the total 
LPD in Bali province. While the percentage of profits from LPDs in the 3 districts is very small, only $18.53 \%$ of the total profits of the Bali Province LPDs.

Table 1 - Number, Assets and Profit of LPD in Bali in 2016

\begin{tabular}{lllllll}
\hline County town & $\begin{array}{l}\text { Number of } \\
\text { LPDs }\end{array}$ & $\begin{array}{l}\text { Assets } \\
\text { (Thousands) }\end{array}$ & $\begin{array}{l}\text { Flat Asset } \\
\text { Score }\end{array}$ & Profit & $\begin{array}{l}\text { Percentage of } \\
\text { Profit }\end{array}$ & $\begin{array}{l}\text { Average } \\
\text { Profit }\end{array}$ \\
\hline Denpasar & 35 & $1,625,610,986$ & $46,446,028$ & $70,217,525$ & $13.01 \%$ & $2,006,215$ \\
Badung & 122 & $4,192,183,809$ & $34,362,162$ & $136,001,473$ & $25.19 \%$ & $1,114,766$ \\
Buleleng & 169 & $1,772,883,196$ & $10,490,433$ & $65,030,828$ & $12.05 \%$ & 384,798 \\
Jembrana & 64 & $480,650,310$ & $7,510,161$ & $19,660,173$ & $3.64 \%$ & 307,190 \\
Tabanan & 307 & $1,284,687,193$ & $4,184,649$ & $45,779,553$ & $8.48 \%$ & 149,119 \\
Gianyar & 270 & $3,286,120,615$ & $12,170,817$ & $103,188,535$ & $19.11 \%$ & 382,180 \\
Bangli & 159 & $759,271,535$ & $4,775,293$ & $34,220,565$ & $6.34 \%$ & 215,224 \\
Klungkung & 117 & $626,241,734$ & $5,352,493$ & $30,667,003$ & $5.68 \%$ & 262,111 \\
Karangasem & 190 & $1,042,893,544$ & $5,488,913$ & $35,128,814$ & $6.51 \%$ & 184,888 \\
\hline total & 1,433 & $15,070,542,922$ & $10,516,778$ & $539,894,469$ & $100.00 \%$ & $376,758,178$ \\
\hline
\end{tabular}

Source: LP LPD Bali Province in 2017.

This low LPD profitability gives one sufficient picture that the LPD shows less than optimal performance. In general, LPD health is strongly influenced by many factors. One that is used as a benchmark that is the object of LPD examination conducted by LPD supervisors. CAMEL consists of five criteria, namely capital, assets, management, income and liquidity. Further described briefly about CAMEL, as a method for measuring LPD health as follows:

1) Capita I, for the capital adequacy ratio. Assessment of capital factors includes an assessment of the following components: a. adequacy, composition, and projections (forward trends) of capital and LPD capital capacity in covering problem assets, b. the ability of LPDs to maintain the need for additional capital derived from profits, LPD capital plans to support business growth, access to capital sources, and financial performance of shareholders to increase LPD capital.

2) Assets, for asset quality ratio. Assessment of asset quality factors includes an assessment of the following components: a. quality of earning assets, concentration of credit risk exposures, development of problematic earning assets, and adequacy of earning assets losses (PPAP), b. adequacy of virtue and procedures, internal review system, documentation system, and problematic handling of productive assets.

3) Management, to assess the quality of management. Assessment of management factors includes an assessment of the following components:

a. General management quality and risk management implementation,

b. LPD compliance with applicable provisions.

4) Earning, for LPD profitability ratios. Assessment of profitability factors includes an assessment of the following components: a. achievement of return on assets (ROA), return on equity.

Based on data from the Lembaga Pemberdayaan LPD Bali Province in 2017, obtained a description of where the health LPD as in Table 2.

From the table, it can be seen that most LPDs are classified as healthy, however, there are still many LPDs that are classified as healthy, unhealthy and even congested. Regarding the health level of LPDs, based on the biplot analysis, it is known that LPDs that are in a healthy and quite healthy category are influenced by management aspects and relatively high liquidity, while the CAR and $L D R$ values are in the average $L P D$ value (BI, 2016). This fact shows the importance of management aspects that are supported by relatively high liquidity to keep LPD in a healthy condition. Meanwhile LPD which is categorized as unhealthy is caused by the high value of $B O P O$ and LDR. This fact shows that the LPD with high operating costs, coupled with the high value of the $L D R$ would have the risk of becoming unwell. Meanwhile, unhealthy LPDs are affected due to the high KAP value, even though the $C A R$ value is high. This means that even though LPD has good capital adequacy, if the quality of its productivity assets $(K A P)$ is high, it will have the opportunity to make the LPD 
less healthy. Even though LPD is the main choice of the community. From the results of a survey of people's preferences for financial institutions when there are several options for financial institutions to save funds, it is seen that $88 \%$ of the public will choose LPDs if there are only LPDs in the area, while if there are other financial institutions such as banks Public, Cooperatives, Regional Development Banks and Rural Banks, the people's choice of LPDs is still quite large, with more than $70 \%$ of the public still prioritizing LPDs (BI, 2016). So it's a pity that there are many LPDs the problem is that in general the health problems of LPDs in Bali are caused by the number of bad loans. This is because LPD management is not professional in managing.

Table 2 - Health Classification of LPD in Bali Tabun 2017

\begin{tabular}{|c|c|c|c|c|c|c|c|}
\hline No. & Year & Healthy & C. Healthy & K. Healthy & T. Healthy & Jam & Total \\
\hline 1 & 2008 & 1,000 & 141 & 49 & 96 & 70 & 1,356 \\
\hline 2 & 2009 & 1,012 & 147 & 57 & 91 & 72 & 1,379 \\
\hline 3 & 2010 & - & - & - & - & - & - \\
\hline 4 & 2011 & 1,011 & 124 & 108 & 43 & 132 & 1,418 \\
\hline 5 & 2012 & 982 & 145 & 106 & 47 & 138 & 1,418 \\
\hline 6 & 2013 & 1,014 & 116 & 90 & 64 & 138 & 1,422 \\
\hline 7 & 2014 & 994 & 133 & 79 & 216 & - & 1,422 \\
\hline 8 & 2015 & 956 & 189 & 93 & 18 & 177 & 1,433 \\
\hline 9 & 2016 & 972 & 164 & 118 & 31 & 148 & 1,433 \\
\hline 10 & 2017 & 864 & 249 & 130 & 44 & 146 & 1,433 \\
\hline
\end{tabular}

Source: LP LPD Bali Province in 2017.

Non-performing loans can be caused by management that does not carry out procedures in granting credit, which is based on $5 \mathrm{C}$ : character, capacity, capital, colateral, and condition. In addition to these factors, bad credit can be caused by the type of credit that is channeled more on consumer credit. Because consumer credit has a higher risk of traffic compared to business loans so that the provision of consumer credit must be more guided by the $5 \mathrm{C}$ principle. The finding of the factor analysis results shows that the factors that influence bad credit at the Village Credit Institution in East Denpasar Subdistrict are internal factors and external factors, while the most dominant factors affecting non-performing loans at Village Credit Institutions in East Denpasar District in 2010-2012 are from internal factors, namely lack of credit supervision with varimax rotation value of 0.866 . (KT Windartini, et al., 2014).

To be able to improve the performance of the LPD, management must be able to establish a business strategy in accordance with the objectives of the LPD organization. The business strategy is expected to serve as a step to improve performance in order to achieve LPD goals. The role of the government in developing the LPD is very significant, besides that the management who is professional in managing LPDs is something that must be owned by management and employees. Professional management can only be done by people who have the capacity / social capital that is sufficient and has the soul of a high social entrepreneurship orientation. With adequate social capital, individuals who have a high social entrepreneurial orientation, enable LPD management to optimally utilize existing opportunities with creativity and innovation and use of available resources.

The role according to Cohen (2009) is a behavior that is expected by others from someone who occupies a certain status. According to Thoha (2002), role is a series of behaviors that are expected to be done by someone. Such an award is a norm that can lead to a role. In organizational language, roles are derived from job descriptions. The job description is a written document that contains the requirements and responsibilities for a job. Because the essence of the role is the embodiment of the interaction between people in the organization. So much can be done by him to plan interventions towards change, improvement and improvement of the organization.

According Suhady in Riawan (2005), the government (government) in terms of understanding is the authoritative direction and administration of the affairs of men / women in a nation state, city, etc. Government can also be interpreted as the governing body of a 
nation, state, city, etc. that is an institution or agency that organizes a state, state, or city government and so on. The definition of government is seen from its nature, namely the government in a broad sense includes all power, namely the legislative power, executive power, and judicial power. The government in a narrow sense only covers the branch of executive power (Riawan, 2005).

According to Sumarni (2013), the need for the role and function of the government in the economy is as follows:

1) Economic development in many countries generally occurs due to government intervention both directly and indirectly. Required government intervention in the economy to reduce the failure of the market (market failure) as monopoly price stickiness and the negative impact of private business activity eg environmental pollution.

2) The market mechanism cannot function without the existence of rules made by the government. This rule provides a basis for the application of the rules of the game, including the imposition of sanctions for economic actors who break them.

The role of the government is more important because the market mechanism alone cannot solve all economic problems. To ensure efficiency, equity and economic stability, the role and function of government is absolutely necessary in the economy as a controller of market mechanisms. The failure of the market (market failure) is a term given to the market failure in achieving the allocation or distribution of optimum resource. This can especially occur if the market is dominated by suppliers of monopoly of production or consumption and a product results in a side effect (externality), such as damage to the environmental ecosystem.

In the development of an effective and optimal government role LPD is realized as a facilitator, regulator and catalyst. 1) The role of the government as a facilitator, as a facilitator, the government has a role in facilitating LPDs to achieve business development goals owned by LPDs. 2) The role of the government as a regulator, is to make policies that make it easier for LPD businesses to develop their businesses. As a regulator, the government functions to maintain the condition of the business environment remains conducive to making investments made by making policies on business competition rules. The government is the party that is able to apply the rules so that life can run well and dynamically. 3) The role of the government as a catalyst, which is to help accelerate the process of developing LPDs.

Social entrepreneurship orientation refers to the processes, practices and decisionmaking that led to the new input and has four aspects, namely entrepreneur (entrepreneur), the idea / notion (idea), opportunities (opportunity), and organization (organization). The entrepreneurial dimension refers to an attitude of someone who has talent or talent, is creative, and has great motivation. Ideas / ideas are translated as orientations to reduce / overcome problems and have ideas for carrying out social activities. Meanwhile, opportunities are understood as being persistent, sensitive to the surrounding environment and the desire to change towards a better one. While the organization is defined as clever set a strategy, implement activities ma shifts and take bold decisions (self-determination).

The orientation of social entrepreneurship is the main driver of profit so that organizations with a high social entrepreneurship orientation have greater opportunities to bring up opportunities and take benefits that ultimately affect business performance. Social capital is a concept that arises from the results of interaction in society with a long process. Even though interactions occur for various reasons, people interact, communicate, and then collaborate are basically influenced by desires in various ways to achieve common goals that are often different from their own goals. This kind of interaction gives birth to social capital in the form of an emotional bond that unites people to achieve a common goal, which then fosters the trust created by the relationship.

With the existence of social capital in an LPD, it will be able to build a network to achieve the objectives of the institution. The strength of this collaboration will be maximal if it is supported by a proactive spirit to make the relationship above the principles of a participatory attitude, mutual attention, giving and receiving, trusting, and reinforced by the values and norms that support it. The LPD as the teacher of the village economy is strongly 
influenced by the adequacy of social capital owned by the local community. This research is based on the models obtained from the phenomena in the field that are formed based on separate theories between models, so that from some of the supporting theories obtained a form of model, the theory and model used in this research is the performance of the institution. With various considerations already stated above, the title of this research is the influence of government roles, social capital and social entrepreneurship orientation on the performance of the Village Credit Institutions (LPD) in the province of Bali.

\section{LITERATURE REVIEW}

Economic growth means the development of economic activity that causes the existing goods and services in society to increase from one period to another and the prosperity of the community increases. The problem of economic growth can be seen as a problem in the macro economy for the long term. In addition, economic growth is influenced by increased investment, developing technology, and increased employment opportunities (Laili, 2007).

The economic growth theory that is relevant to this research is Schumpeter's theory of economic growth known as the Schumpeter Theory. According to Sukirno (2006), this theory emphasizes innovation carried out by entrepreneurs and says that technological progress is largely determined by the entrepreneurial spirit in a society that is able to see opportunities and dare to take the risk of opening a new business, as well as expanding existing businesses. With the opening of new businesses and business expansion, additional employment is available to absorb the growing workforce each year.

According to Arsyad (2010), this Schumpeter theory was first proposed by Joseph Alois Schumpeter in his German-language book in 1911 which was later published in English in 1934 under the title The Theory of Economic Development. Then it was further examined in theory about the development process and the main factors that determine development in his book published in 1939 under the title Business Cycle. One of Schumpeter's opinions that became the foundation of his development theory was the belief that the capitalism stem was the best system for creating rapid economic development. However, Schumpeter predicted that in the long run the capitalism system would stagnate. This opinion is the same as the opinion of the classics.

Understanding Roles according to Cohen (2009) is a behavior that is expected by others from someone who occupies a certain status. According to Thoha (2002), role is a series of behaviors that are expected to be done by someone. Such an award is a norm that can lead to a role. In organizational language, roles are derived from job descriptions. The job description is a written document that contains the requirements and responsibilities for a job.

According Suhady in Riawan (2005), the government (government) in terms of understanding is the authoritative direction and administration of the affairs of men / women in a nation state, city, etc. Government can also be interpreted as the governing body of a nation, state, city, etc. that is an institution or agency that organizes a state, state, or city government and so on. The definition of government is seen from its nature, namely the government in a broad sense includes all power, namely the legislative power, executive power, and judicial power. The government in a narrow sense only covers the branch of executive power (Riawan, 2005).

The beginnings of the thoughts of economists on social capital, had begun in the 18th century, when Adam Smith raised the concept of social capital as a 'social contract' of civil society which would determine the progress of economic development. An important element of this social contract is among others what they refer to as; characteristics of social networks, reciprocal patterns and mutual obligations. Of these group thoughts too, various studies and a modern concept of social capital in the next century, have a strong theoretical basis. Coleman (1998) defines that social capital is an aspect of social structure that facilitates the actions of individuals or corporate / institutional actors in the social structure. Furthermore it is said that social capital is not a single entity, but is a plural entity with two fundamental elements namely; 1) social capital covers several aspects of social structure, 
and 2) social capital facilitates certain actions of actors (actors) as individuals and institutions within the structure. In this case it means; similar to other types of capital, social capital is also productive, which makes the achievement of individual or institutional goals will not materialize without the existence of social capital. Furthermore, Putnam (1993) defines that social capital is the appearance of social organizations, such as wealth, reciprocity, networks that can improve the efficiency of society by facilitating coordination and cooperation for mutual benefits.

The Social Capital Indicator is very broad in scope. In this study, collaborating indicators of social capital put forward by Hasbullah (2006) called it the main elements of social capital. Furthermore, it is said that the study of social capital lies in how the ability of the community in a group entity to participate in building a network to achieve a common goal. The collaboration is characterized by a mutually beneficial reciprocal interaction pattern, and is built on trust that is supported by positive and strong social norms and values. While Ridell in Ayu Wimba (2015), said there are three parameters of social capital, namely: (1) networks, (2) trust, and (3) norms.

By combining the concept of the two experts at the top, and with emphasis on compliance with the conditions in research then expressed as an indicator in the study i ni is; 1) participation in the network, 2) exchanging goodness, 3) trust, 4) norms, 5) values and 6) proactive actions.

Hasbullah (2006) distinguishes the typology of social capital into two things, namely 'binding' social capital and 'bridging' social capital. Social capital is binding, tends to be exclusive. What is the basic characteristic inherent in this typology, is at the same time expressed as a characteristic. That is, in the context of ideas, relations and attention appear to be more oriented into groups, when compared to being oriented outside the group.

Entering a knowledge-based economic era, the world including Indonesia will face more competitive job competition. The world also needs entrepreneurs who care spiritually, humanism, and social aspects of human life to bridge the gap between strong and weak, rich and poor, and provide a harmonious balance between life and nature. Complex problems such as global warming, corruption, poverty, global economic problems and so on are homework for every citizen in the world. As the world needs entrepreneurship, social entrepreneurship is also needed as a balance between a competitive world and a harmonious life.

The main purpose of social entrepreneurship is to improve social life and a better environment. Although social entrepreneurship is often non-profit, it also does not conflict with business that is profitable. Social entrepreneurship is more than making profit, by using a mixture of business model values that combine with income-generating businesses with structures or components that create social value. Entrepreneurship has not only become a driving force for the growth of the business sector, but has also been the driving force behind the expansion of the social sector. Social entrepreneurship, or entrepreneurial activities with social goals have increased in recent decades. One indicator of this surge is expressed by the rapid growth in the number of non-profit organizations. The definition of social entrepreneurship definition can be expanded or narrowed down. Based on a narrow definition, social entrepreneurship refers to the phenomenon of applying market-based business skills and skills to the nonprofit sector by developing innovative approaches to earning income (Reis, 1999; Thompson, 2002).

One of the benchmarks for achieving or not the purpose of the LPD is the assessment of the performance of the institution. LPD is an institution whose management is identical like managing an institution. Therefore in measuring the performance of the institution it is almost the same in measuring the performance of the institution. All agency activities are mobilized to achieve their objectives. That is, the purpose of the institution is the end result that is pursued through the existence and all operations of the institution, in this case for example; continuity or continuity, profitability, efficiency, employee satisfaction and coaching, product quality or service to consumers, social responsibility, market leadership and others (Gluck \& Jauch 1988). Thus all the efforts of the institution to achieve its objectives are usually measured through an assessment of the performance of the institution. 
Keats \& Hitt, (1988) states that the assessment of institutional performance has important value because, in addition to being used as a measure of the success of an institution in a certain period. The performance assessment can also be used as feedback for improvement or improved performance in the future will come. Therefore, an assessment of the performance of an institution must be carried out, because the results of this assessment can be used as a basis for information to improve business performance for the future. Beal (2000) states that "There is still controversy regarding the right approach to conceptualization and measurement of institutional performance."

In essence LPDs have very specific characteristics. Its flexible, highly dynamic nature including limitations and weaknesses attached to it, such as the quality of management that is still very low, the limitations of human resources, causing the assessment of its performance must use a separate pattern. In this study, business performance will be directly analyzed based on the balanced scorecard perspective, so that as a business performance indicator are: financial performance, customer performance, internal business process performance and growth and learning performance.

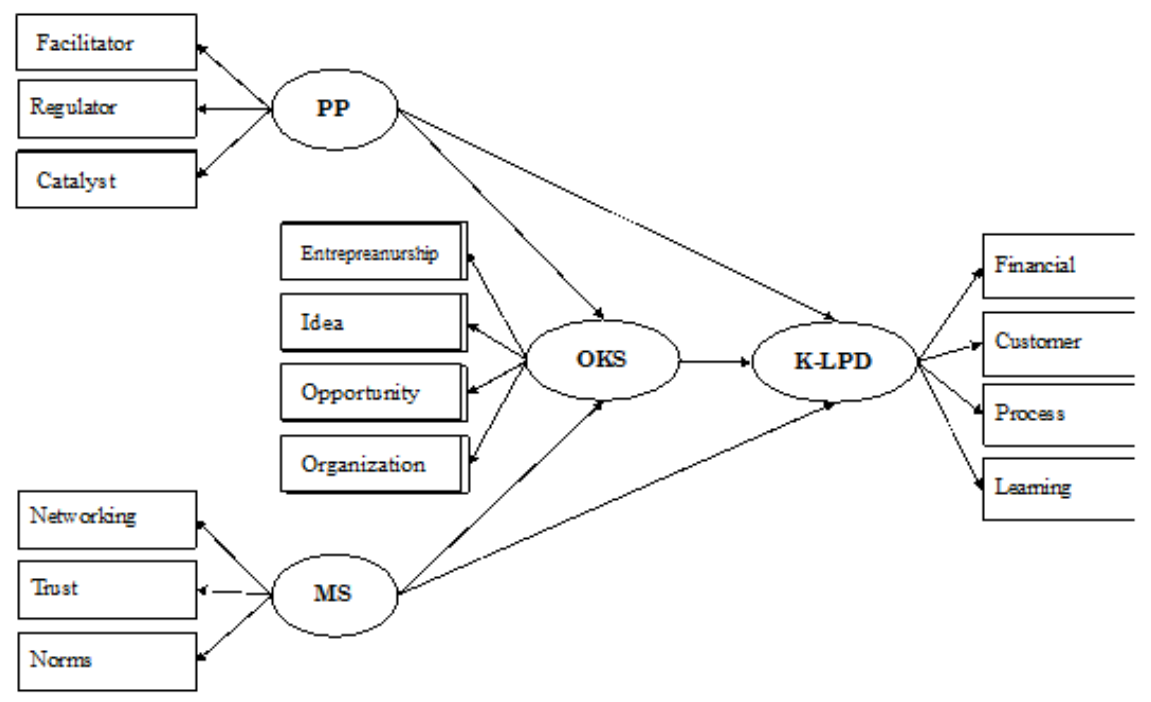

Figure 1 - Conceptual Framework

Note: PP - The Role of Government; MS - Social Capital; OKS - Social Entrepreneurial Orientation; KLPD - LPD Performance.

Based on the review of the theory and empirical studies, in this study 7 (seven) hypotheses are proposed which the truth will be tested through the research process:

- The role of the Government influences the Social Entrepreneurship Orientation and LPD Performance at LPDs in Bali Province;

- Social Capital influences the Social Entrepreneurship Orientation and LPD Performance at LPDs in Bali Province;

- Social Entrepreneurship Orientation influences the performance of LPDs in Bali Province;

- Social Entrepreneurship Orientation mediates the Role of Government and Social Media on the Performance of LPDs in Bali Province.

\section{METHODS OF RESEARCH}

Considering that this research is still explorative and to harmonize with data analysis techniques used, the error rate is set at 10 (ten) percent. The sampling technique must, of course, be adjusted to the number of LPDs in each district / city in the province of Bali. Due to the number of different populations is different for each district / town, and then the appropriate sampling technique is a technique Proportional Random Sampling. As a basis for 
the argumentation, the technique of determining this sample is proportional because the number of population in each district / city is different; while random is to provide an opportunity equal to every member of the population to be sampled. A description of the method and technique for determining the sample is presented in Table 3.

Table 3 - Population Distribution and Research Samples at LPDs in the province of Bali in 2016

\begin{tabular}{llll}
\hline No. & Regency / City & Total population & Calculation of Stratified Samples \\
\hline 1 & Denpasar & 35 & 2 \\
2 & Badung & 122 & 8 \\
3 & Gianyar & 270 & 18 \\
4 & Tabanan & 307 & 20 \\
5 & Jembrana & 64 & 4 \\
6 & Buleleng & 169 & 11 \\
7 & Karangasem & 190 & 12 \\
8 & Bangli & 159 & 10 \\
9 & Klungkung & 117 & 8 \\
\hline & & 1,433 & 93 \\
\hline
\end{tabular}

Source: LPLPD Bali Province 2016 (processed).

In data collection in this study used indirect communication techniques. The indirect communication media are questionnaires or questionnaires to obtain data from respondents. The questionnaire is a list of written questions that have been prepared previously. This questionnaire is expected to collect research data, namely quantitative data with ordinal scale.

A study, whether conducted by an inductive approach or a deductive approach still requires testing the validity and reliability of the research instrument used. This validity and reliability test is carried out with the aim of ensuring the accuracy and consistency of the data needed.

\section{RESULTS OF STUDY}

Based on the research conducted, it was obtained a description that most respondents had ages between 40 to 49 years, amounting to 29 people or 30.53 percent. Then in the second place, are respondents who have the age between 50 to 59 years, namely a number of 27 people or 28.42 percent. In the third place, are respondents who have the age between 30 to 39 years, amounting to 21 people or 22.11 percent. While at least that is in the fifth place is the respondent who has more than 59 years of age, namely 5 people or 5.26 percent. Thus it can be stated that the majority of respondents are in the productive age, namely from the age of 20 to 49 years which is 66.32 percent.

Respondents has a high school education level of 67 people or 70.53 percent. Followed by a Bachelor / Diploma education level of 26 people or 27, 37 percent. While those who have Postgraduate education only 2 people or 2, 11 percent. The respondent's work time is quite varied, some are only one year until there are more than 12 years. Most respondents have a work period of 1 - 8 years. Most respondents have a working period of 5 8 years, namely 41 people or 43,16 percent. Followed with a work period of 1 - 4 years as many as 33 people or 34,74 percent. Whereas those who have a work period of more than 12 years $\mathrm{h} 8$ people or 8,42 percent. The sex of the respondents is dominated by men. Seen as many as 60 people or 63,16 percent of respondents were male. Followed by as many as 35 people or 36, 84 percent female.

Research requires valid and reliable data. In the context of this urgency, the questionnaire before being used as a primary research data collector must first be tested. This test is carried out to obtain evidence of the accuracy and accuracy of the measuring instrument in the form of a question / statement item in performing its measuring function. Testing instrument research includes validity and reliability. Based on the results of the tests that have been carried out, all variable statement items are valid. Thus, all items of the variable statement are valid to measure all variables, so that they are included in further 
analysis. A list of questions can be said to be reliable if it has a Cronbach's value> 0.60 . From processing SPSS for Windows version 24.0, the Cronbach's Alpha coefficient is $>0.60$. This means that the list of statements (questionnaires) of all variables is reliable.

The results of this analysis, it was confirmed 4 (four) latent constructs with supporters of each indicator are: variable Role of Government, Social Capital, Social Entrepreneurship Orientation and Performance LPD there were no indicators that the value of outer loading of less than 0.5 . Thus it can be stated that, all latent constructs with reflective indicators have met convergent validity requirements.

The results of the primary data analysis show the $R$ Square coefficient index as presented in Table 5.19. While to determine the suitability of the model (Goodness of Fit Model Test) is to use the predetermined Q2 formula (Ghozali, 2011), as shown below. The calculation of the suitability of the model in this study is calculated based on the $R$ Square value in Table 5.

Table $5-R$ Square The Role of Government, Social Capital, Social Entrepreneurship Orientation and LPD Performance in Bali Province

\begin{tabular}{llllll}
\hline & Original Sample (O) & Sample Mean $(M)$ & Standard Error (STERR) & T Statistics (| O / STERR ) & $P$ Values \\
\hline KLPD & 0.645 & 0.657 & 0.063 & 10,227 & 0,000 \\
OK S & 0.440 & 0.449 & 0.079 & 5,570 & 0,000 \\
\hline
\end{tabular}

Source: Results of Primary Data Analysis.

Based on the $R^{2}$ values shown in Table 5.29, the $Q^{2}$ values can be calculated:

$$
Q^{2}=80,12
$$

The predictive relevance value of $Q^{2}=0.8012$ is interpreted that the model is good enough, which is able to explain the phenomenon of the influence of Government Role and Social Capital on Social Entrepreneurship Orientation and LPD Performance in Bali Province. That is, optimization of 80.12 percent LPD performance is able to be explained by the latent variables Role of Government, Social Capital and Social Entrepreneurship Orientation, while the remaining 19.88 percent is explained by other variables not included in the model. To be able to provide more in- depth clarity about the results of the analysis, the following is presented by the full results of the structural model of the study. More can be seen in Figure 2.

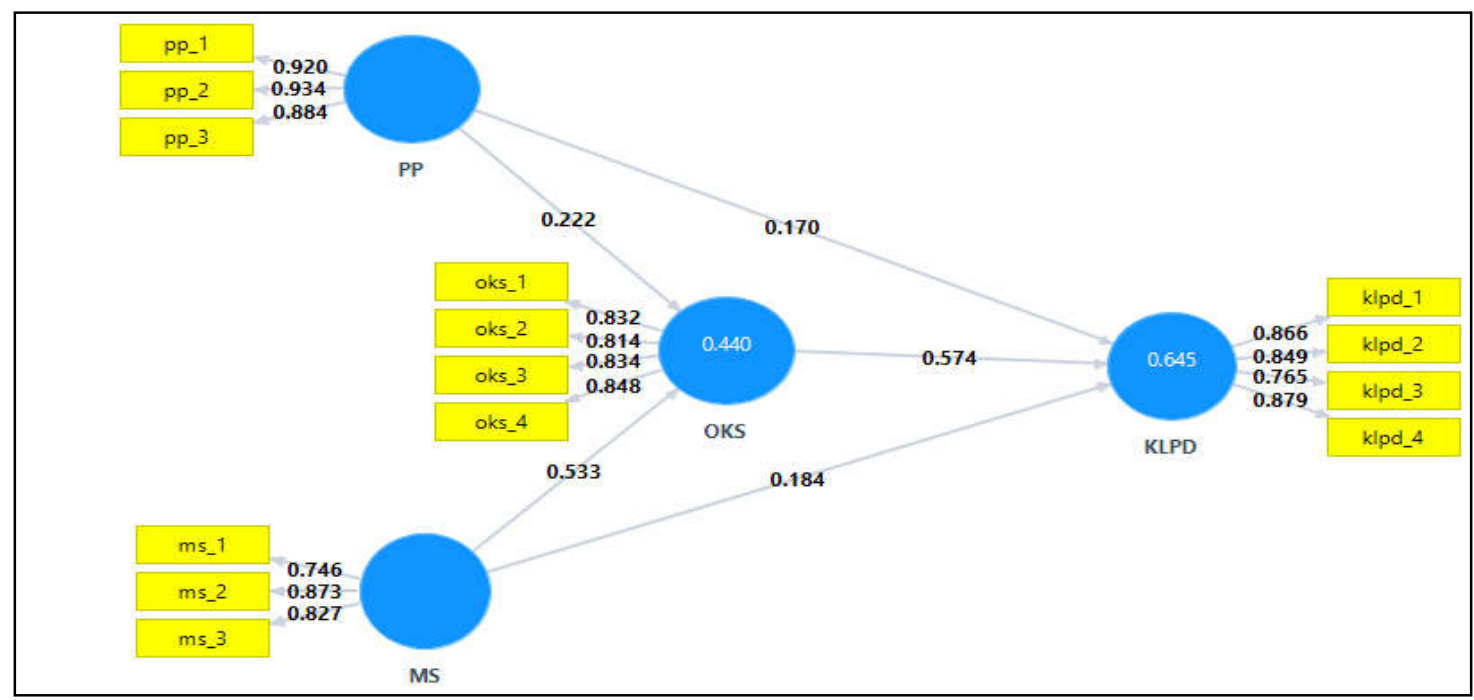

Note: PP - The Role of Government; MS - Social Capital; OKS - Social Entrepreneurial Orientation; KLPD - LPD Performance.

Figure 2 - Structural Model of the Influence of the Role of Government, Social Capital and Social Entrepreneurship Orientation to Improve LPD Performance in Bali Province 
Based on Figure 2, there are several things that must be observed and get a deeper understanding, namely about indicators that show the largest loading, and its meaning on the existence of these indicators. In more detail, the meaning is explained as follows. In the Government Role variable, the largest loading value is on the regulator indicator, with a coefficient index of 0.934 . case indicates that the policy or rules relating to the operational LPD is still needed and got a high appreciation of the LPD staff. Regional regulations are made to provide certainty of business processes that occur.

For the Social Capital variable, among the three indicators that construct latent variables, the confidence indicator has the largest loading value, with outer loading 0.873 . This empirical fact proves that trust / mutual trust is the key to successful LPD development. The biggest loading factor on the latent variable Social Entrepreneurship Orientation is the organization, the ability to manage strategy and dare to make decisions, with a coefficient index of 0.848 . Latent variable LPD performance, which in this case is supported by four indicators, turns out the most dominant is growth and learning performance, with the outer weight coefficient index of 0.879 . The response of LPD administrators is also very good with this indicator.

Research Hypothesis Testing. Testing the hypothesis in this study, based on the significance value shown in each path between the latent constructs in the research model. In general, the significance value of probability ( $p$-values) below $0.05(p<0.05)$ provides instructions for stating that the effect is stated to be significant, both directly and indirectly.

The relationship between latent constructs in this study is shown by 7 (seven) forms of research hypotheses. To test the hypothesis used to seven structural model equations by applying a PLS, with software (software) SmartPLS version 3.0 In detail, the influence between the latent constructs to test the hypothesis presented in Table 6.

Table 6 - Final Results Path Coefficients Role of Government, Social Capital, Social Entrepreneurship Orientation and LPD performance in Bali Province

\begin{tabular}{|c|c|c|c|c|c|c|}
\hline & $\begin{array}{l}\text { Original } \\
\text { Sample } \\
\text { (O) }\end{array}$ & $\begin{array}{l}\text { Sample } \\
\text { Mean } \\
\text { (M) }\end{array}$ & $\begin{array}{l}\text { Standard } \\
\text { Error } \\
\text { (STERR) }\end{array}$ & $\begin{array}{l}\text { T Statistics } \\
(|,| \\
\text { STERR | }\end{array}$ & $\begin{array}{l}P \\
\text { Values }\end{array}$ & $\begin{array}{l}\text { Decision } \\
\text { Hypothesis } \\
\text { testing }\end{array}$ \\
\hline MS -> KLPD & 0.184 & 0.185 & 0.094 & 1,967 & 0.025 & Significant \\
\hline MS -> OKS & 0.533 & 0.530 & 0.085 & 6,285 & 0,000 & Significant \\
\hline OKS -> KLPD & 0.574 & 0.574 & 0.106 & 5,426 & 0,000 & Significant \\
\hline PP $\rightarrow$ KLPD & 0.170 & 0.172 & 0.075 & 2,280 & 0.012 & Significant \\
\hline PP $\rightarrow>$ OKS & 0.222 & 0.224 & 0.081 & 2,753 & 0.003 & Significant \\
\hline
\end{tabular}

Source: Results of 2018 Primary Data Analysis

Based on the presentation in Table 6 it can be explained that: The latent construct of social capital has a positive and significant effect on LPD performance with 0.184 path coefficients; t-statistics 1.967 and probability value 0.025 ; the latent construct of Social Capital has a positive and significant effect on the latent construct of Social Entrepreneurship Orientation with path coefficients 0.533 ; t-statistics 6,285 and value probability 0,000 . Likewise, the latent construct of the Social Entrepreneurship Orientation also has a positive and significant effect on LPD performance with 0.574 path coefficients; $t$-statistics 5.426 . and value probability 0,000 .

Similarly, the latent construct of the Government's Role also has a positive and significant effect on the latent construct of LPD Performance with 0.170 path coefficients; $t$ statistics 2,280 and value probability 0,000. Likewise, the latent construct of the Role of the Government influences positively and significantly on the latent construct of Social Entrepreneurship Orientation with the path coefficients 0.222 ; $t$-statistics 2.753 . and value probability 0.003 . While the influence between latent constructs is positive and significant because it has $t$-statistics more than 1.96 and probability values less than 0.04 (Ferdinand, 2012). 


\section{DISCUSSION OF RESULTS}

The results of testing the hypothesis prove that the role of government has a positive and significant influence on social entrepreneurial orientation. This finding indicates that the maximum role of the government will be able to improve the quality of social entrepreneurial orientation of LPD managers in Bali Province. In this connection it can be understood that the meaning of government support is in the form of facilities, regional regulations and capital support. This was supported by the results of an interview with the Tabanan Regency LPLPD head, namely I Dewa Nyoman Alit Astina, SE. Alit Astina said:

That the government's role so far has been very good in supporting the existence of LPD, between the role of government has done that work together in to guide the LPD board in the form of mentoring and training. With this routine guidance, it is possible for LPD administrators to gain new knowledge which will increase the power of creativity and innovation in developing institutions. Thus the quality of LPD human resources (HR) will continue to increase.

Therefore, the guidance made by the government is very important because it can improve the creativity and innovation of LPD administrators, which in turn will be able to improve LPD performance.

The results of testing the hypothesis prove that social capital has a positive and significant influence on social entrepreneurship activities. This finding indicates that the good functioning of social capital will improve the quality of social entrepreneurial orientation of LPD managers in Bali Province. In this connection it can be understood that how meaningful togetherness is imbued by active participation to carry out networking activities, trust among staff, and adhere to norms imposed in one community. In an interview, I Gede Saniara, SE (Former Head of the LPD in Buleleng) said that:

Why is the LPD trusted by the community, because the LPD management has a high commitment to help the public's integrity. If the community / LPD members have financial problems, the LPD is ready to help provide loans, both of which have a small to large nominal value. The level of trust of LPD administrators to customers / members is very high, because besides they are villagers, also generally LPD administrators know exactly the profile / condition of the village community. In addition, LPD officials also always uphold the norms that apply in the village.

With the formation of networks, mutual trust between LPD officials and customers is increasing which will then broaden the horizons of social entrepreneurship orientation.

Hypothesis test results of this study indicate that social entrepreneurial orientation has a positive and significant effect on LPD performance. The positive relationship between social entrepreneurial orientation and LPD performance, indicates a mutually supportive relationship between measurable indicators of social entrepreneurship orientation and measurable indicators of LPD performance. The higher the perceptions given to assess indicators of social entrepreneurship orientation, the higher the assessment given to LPD performance. I Nyoman Arnaya, SE (Chair of the LPLPD of Bali Province ) said that:

At present a breakthrough is needed from the LPD, because currently there are many LPDs that are excess money where many LPD members save money, the LPD board must think creatively and innovatively, make efforts / encourage the community to open a business / business where the LPD collaborates with the community. The LPD funds the business / business carried out by its members. Thus there will be mutually beneficial cooperation between LPDs and members / customers.

The demand for many creative ideas / ideas to develop LPD is very necessary. Continuous development of local wisdom will enrich LPD thinking. The strong creative ideas and oriented solutions to the problems contained in the social entrepreneurship orientation allow LPD administrators to produce the best work to develop their institutions.

The training obtained by LPD staff, the certainty of business rules created by the local government and the provision of capital assistance will greatly assist the LPD manager to develop his business. So far the local government has always provided guidance to LPD LPDs by appointing BPD as a government partner to foster LPDs, so that it can be said that 
government support for LPD performance improvement is very significant, explained $\mathrm{Ni}$ Wayan Ersi, Chair of Jero Kuta LPD, Gianyar). This was corroborated by I Nyoman Arnaya, SE who also served as Chairman of the Bali Province LPLPD. Arnaya said:

"The role of local governments in supporting the existence / existence and development of LPDs is in line with what is expected. The form of government support through the BPD, both in the form of helping to save LPD money and in the form of providing technical guidance to the existing LPD management, by holding vocational training training. Arnaya added that why LPD needs to be supported, because the LPD is a financial institution at the village level, which is expected to be the driving force of the local village economy. Moreover, this has been in accordance with the presidential program Nawacita program, Jokowi that we build a nation starting from the countryside and populist based ".

Ni Wayan Ersi and I Nyoman Arnaya's views were strengthened by the opinion of I Ketut Giri Arta, S.Pd., MM the head of Pecatu Badung LPD that the role of the government had been good, facilitating, protecting and supporting the LPD program.

Testing the hypothesis in this study proves that social capital has a positive and significant effect on LPD performance. The positive relationship between social capital and LPD performance indicates a mutually supportive link between measurable indicators of social capital and measurable indicators of LPD performance. Social capital which in this case is measured by active participation in the network, mutual trust, running a business in accordance with norms can provide a convincing increase in LPD performance as measured by financial performance, customer performance, internal business process performance and growth and learning performance.

The results of the research data analysis legitimize, that the Social Entrepreneurship Orientation mediates partially mediated the Government's Role on the performance of LPDs in Bali Province. The results of this study prove that the Social Entrepreneurship Orientation is not strong enough to mediate the role of government in LPD performance.

The findings of this study indicate that based on the mediation model, social entrepreneurial orientation mediates partially mediated on the relationship between the role of government and LPD performance. However, convincingly social entrepreneurship orientation can improve LPD performance. This means that the implementation of social entrepreneurship orientation that is getting better in business activities carried out through entrepreneurial attitudes, rich in ideas / ideas, good at finding opportunities and able to find solutions will direct the institution to improve its performance. I Ketut Giri Arta, S.Pd., MM the head of Pecatu Badung LPD said:

The development of village credit institutions (LPD) is very rapid today because it utilizes local wisdom (local genius). In addition, further Giri Arta hopes that in order to win the competition in business in the future, the LPD must apply modern management, using information technology (IT), besides that LPD stake holders cannot be left behind.

Ideas / ideas become one of the most valuable investments in developing LPDs. As with the current developments, there is a phenomenon of creative economy, which is based on creative and innovative ideas / thoughts in developing the economy.

The results of the study found that the Social Entrepreneurship Orientation mediated partially mediated Social Capital towards LPD Performance. In this mediation model, the Social Entrepreneurship Orientation mediates part of the influence of Social Capital on LPD Performance. This is shown by the influence of Social Capital on Social Entrepreneurship Orientation and the influence of Social Entrepreneurship Orientation on LPD Performance is significant. Solimun (2004) recommends that based on the mediation model, the Social Entrepreneurship Orientation can be referred to as partially mediate in the relationship of Social Capital to LPD Performance.

Some of the things stated as the main findings of this study are as follows:

First finding: the role of government is formal, in the form of making laws or local regulations governing LPD governance, providing legal certainty which ultimately makes LPD managers work optimally. Especially the role of the government in facilitating (facilitators) LPD is very important where as an element of the government's role that gets the most appreciation from the LPD administrators. This is reinforced by the results of the analysis that 
shows the facilitator indicator has the largest loading factor, namely: 91,8 as a measurable component of the aspect of the government's role.

Second finding: social entrepreneurship orientation mediates (partially mediated) the influence of government roles and social capital on LPD performance. This indicates that the role of social entrepreneurship orientation in facilitating the role of government and social capital to be able to improve the performance of LPD is there even though it is imperfect / maximal.

Third finding: Empirical facts which are also the findings of this study are the LPD managers in Bali Province, placing the aspect of social capital 'trust' as an element of social capital that is most appreciated by the LPD officials in Bali Province. This is reinforced by the results of the analysis that shows the confidence indicator has the largest loading factor, namely: 92.20 as a measurable component of the aspect of social capital. This means that the LPD administrators in Bali Province greatly appreciate this behavior, as personal capital and social glue that must be owned, to maintain the sustainability of social entrepreneurial orientation that will guarantee the development of LPDs.

Fourth finding: This study also found that for social entrepreneurship orientation variables, the most appreciated is 'ideas / ideas to improve welfare in the surrounding environment' with a perception level: 86.52 percent. This finding indicates that LPD managers perceive that the idea / idea to improve welfare in the surrounding environment is the most important thing, compared to other elements of social entrepreneurial orientation.

Fifth Findings: This study also found, for the measured variables of LPD performance, the biggest response as a form of respondent's main concern was 'customer performance' with a perception level: 87.80 percent. Continuously maintaining customer loyalty will be able to build product reputation, which ultimately impacts the reputation of the institution. And so on, sales increase, profits increase significantly, the sustainability of the institution's life can be maintained.

\section{CONCLUSION AND SUGESTIONS}

Based on the results and discussion in this study can be concluded things like the following:

1. The role of the Government and Social Capital has a positive and significant effect on the Social Entrepreneurship Orientation. Where Social Capital plays a greater role in enhancing the LPD Social Entrepreneurship Orientation in Bali Province.

2. The Role of Government, Social Capital and Social Entrepreneurship Orientation positively and significantly influences the performance of LPDs in Bali Province. Where, the Social Entrepreneurship Orientation is the most dominant influence on improving LPD Performance.

3. The orientation of Social Entrepreneurship mediates partially mediated, the Role of Government and Social Capital in improving the Performance of LPDs in Bali Province.

Some suggestions can be given in accordance with the results of the study, namely:

- It is suggested to LPD officials that they always coordinate with the government in operating their institutions, the role of the government as a facilitator, regulator and catalyst for LPD so far can work well.

- As a result of the research, the role of the government as a facilitator is very significant to help improve LPD performance. Therefore it is recommended that the Government continues to seek support in order to empower the LPD, by giving full support to the LPD indirectly it will also improve the economic welfare of the community because essentially the LPD is one of the central economic of the people in the lowest level of society, namely in the banjar and the village in the province of Bali. 


\section{REFERENCES}

1. Abidin, Said Zaenal, 2012, Kebijakan Publik, Jakarta: Salemba Humanika.

2. Adisasmita, Rahardjo. 2013. Teori-Teori Pembangunan Ekonomi. Yogyakarta: Graha IImu.

3. Agung Aricahya, A. A. Gde., dkk. 2015. Analisis Kinerja Badan Pemberdayaan Masyarakat Dan Pemerintahan Desa Kota Denpasar Dalam Pengelolaan Bantuan Kelurahan. ISSN: 2337-3067 E-Jurnal Ekonomi dan Bisnis Universitas Udayana 4.11 (2015): 759-772

4. Ahmad Erani Yustika et. al. 2008. Krisis Ekonomi, Kontestasi Politik, dan Proyeksi Ekonomi 2000. Jakarta: INDEF

5. Alvarez, Sharon A \& Busenitz, Lowell W. 2001. The Entrepreneurship of Resource Based Theory, Journal Management, 27, pp,755-775

6. Amirin, T., 2011. Populasi Dan Sampel Penelitian 4: Ukuran Sampel Rumus Slovin. Jakarta: Erlangga

7. Anthony, Atkinson, et al., 1995. Management Accounting, International Edition, New Jersey, Englewood Cliffs: Prantice-Hall International Inc.

8. Arikunto, Suharsimi. 1998. Prosedur Penelitian Suatu Pendekatan Praktek. Jakarta: PT. Rineka Cipta.

9. Arikunto, Suharsimi. 2000. Manajemen Penelitian. Jakarta: Rineka Cipta.

10. Arsyad, Lincolin. 2010. Ekonomi Pembangunan. Yogyakarta: UPP STIM YKPN

11. Atmaja, Ananta Wikrama Tungga. 2011. Penyertaan Modal Sosial Dalam Struktur Pengendalian Intern Lembaga Perkreditan Desa (LPD) (Studi Kasus pada LPD Desa Pakraman Penglatan, Kecamatan Buleleng, Kabupaten Buleleng, Provinsi Bali). Ejournal undiksha Jurnal IImiah Akuntansi Dan Humanika. Vol 1, No 1: Edisi Desember 2011

12. Augusty, Ferdinand. 2012. Metode Penelitian Manajemen: Pedoman Penelitian untuk skripsi, Tesis dan Disertai Ilmu Manajemen. Semarang: Universitas Diponegoro.

13. Austin et al., 2004.J.E. Austin, H. Leonard, E. Reficco, J. Wei-Skillern. Corporate Social Entrepreneurship: A New Vision of CSR. Boston: Harvard Business School Working Paper No. 05-021.

14. Ayu Wimba, I Gusti. 2015. Pengaruh Modal Sosial Terhadap Orientasi Kewirausahaan dan Biaya Transaksi untuk Meningkatkan Kinerja Usaha pada UKM Kerajinan Kayu di Provinsi Bali. Disertasi. Denpasar: Universitas Udayana

15. Badan Pusat Statistik (BPS) Provinsi Bali. 2017. Statistik Provinsi Bali 2016: Bali Dalam Angka.

16. Baker W. 2001. Achieving Success Through Social Capital. San Francisco, CA: Jersey Bass

17. Bank Indonesia. 2016. Peranan Lembaga Perkreditan Desa (LPD) dalam Mendukung Perekonimian Bali. Hasil Penelitian. Bali: Kantor Perwakilan Bank Indonesia Denpasar. Tidak Dipublikasikan

18. Beal, Reginald M., 2000. Competing Effectivity Environmental Scanning Competitive Strategy and Organizational Performance the Small Manufacturing Firm, Journal of Small Business Management, Vol. 22. pp.27- 45

19. Bhuono, Agung Nugroho, 2005. Strategi Jitu Memilih Metode Statistik Penelitian dengan SPSS. Yogyakarta: Penerbit Abdi

20. Bornstein, D. 2004. How to Change the World: Social Entrepreneurs and the Power of New Ideas? Oxford: Oxford University Press

21. 2006. How to change the world? Socio entrepreneurs and the power of new ideas. Oxford: Oxford University Press

22. Light, Paul Charles. 2004. Sustaining Nonprofit Performance: the Case for Capacity Building and the Evidence to Support it. Washington, D.C: Brookings Institution Press.

23. 2006. Reshaping Social Entrepreneurship. Stanford Social Innovation Review 
24. Carton, Robert B \& Hofer, Charles W. 2006. Measuring Organizational Performance Matric for Entrepreneurship and Strategic Management Research. Glensanda House, United Kingdom: Published by Edward Elgar Publishing Limited

25. Casson M, Godley A. 2000. Cultural Factors in Economic Growth. Germany. SpringerVerlag Berlin-Heidelberg.

26. Casson, Mark. 2012. Entrepreneurship (Teori, Jejaring, Sejarah). Jakarta: PT. Raja Grafindo Persada

27. Chin, W. W., Gopal, A. and Salinsbury, W.D. 1997. Advancing the Theory of Adaptive Structuration: The development of a Scale to Measure Faithfulness of Appropriation. Information System research, 8: 342-367.

28. Cohen Bruce J. 2009. Peranan, Sosiologi Suatu Pengantar. Jakarta: Rineka Cipta

29. Cohen, D \& Prusak, L. (2001). In Good Company: How Social Capital Makes Organization Work. London: Harvard Business Press

30. Coleman, J.S. 1988. Foundations of Social Theory. Cambridge: Harvard University Press

31. 1998. Social Capital in the Creation of Human Capital, American Journal of Sociology, 94, Supplement. S95-S120

32. Colletta, NJ. Dan Michelle L. Cullen. 2000. Violent Conflict and The Transformation of Social Capital, Lesson from Cambodia, Ruanda, and Somalia. Washington: The World Bank, pp. 1-16.

33. Cooper, D. R and P. S. Schindler. 2006. Business Research Methods. 9th ed. New York: Mc Graw Hill Companies, Inc

34. Covin, J.G, \& Slevin, D.P. 1989. Strategic Management of Small Firms in Hostile and Benign Environments. Strategic Management Journal, 10, 75-8

35. 1991. A Conceptual Model of Entrepreneurship as Firm Behaviour, Entrepreneurship Theory and Practice, 16 (1), 7-25

36. Cox Eva, 1995, A Truly Civil Society. Sydney: ABC Books.

37. Crossan, M.M. and Berdrov, I. 2003, "Organizational learning and strategic renewal". Strategic Management Journal, Vol. 24 No. 11, pp. 1087-105

38. Dart, R. 2004. "The legitimacy of social enterprise", Nonprofit Management \& Leadership, 14:4, 411-424

39. Dasgupta P, Serageldin I. 2002. Social Capital: A Multi-Faceted Perspective. Washington DC: World Bank

40. Dees, J. G. 1998. The Meaning of "Social Entrepreneurship". Graduate School of Business, Stanford University.

41. Dees, J. G. \& Elias, J. 1998. "The challenges of combining social and commercial enterprise". Business Ethics Quarterly, 8:1, 165-178.

42. Fukuyama, Francis. 1995. Trust: Kebajikan Sosial dan Penciptaan Kemakmuran. Yogyakarta: Penerbit Qalam.

43. 1999. Social Capital and Civil Society. The Institute of Public Policy, George Mason University.

44. 2001. Social Capital: Civil Society and Development. Third World Quarterly, Vol 22.

45. 2008. Trust, Kebijakan-kebijakan Sosial. Yogyakarta: Penerbit Qolam.

46. Ghozali, Imam. 2005. Aplikasi Analisis Multivariate dengan Program SPSS. Semarang: BP Universitas Diponegoro

47. 2008. Structural Equation Modelling, Edisi II. Semarang: Universitas Diponegoro

48. 2011. Structural Equation. Modeling, Metode Alternatif Dengan Partial Least Square PLS, Edisi 3. Semarang: BP. Universitas Diponegoro.

49. 2014. Structural Equation Modeling, Metode Alternatif dengan Partial Least Square (PLS). Edisi 4. Semarang: BP. Universitas Diponegoro

50. Glueck, William F. \& Jauch Laurence R. 1988. Business Policy and Strategic Management. New York: Mc Graw Hill

51. Gregory G. Dess and Donald W. Beard. 1984. Dimensions of Organizational Task Environments. Administrative Science Quarterly. Vol. 29, No. 1 (Mar., 1984), pp. 52-73. 
Sage Publications, Inc. on behalf of the Johnson Graduate School of Management, Cornell University

52. Hair, J. F., Black. W. C., Babin. B. J.; and Anderson. R. E. 2010. Multivariate Data Analysis, 7th ed. New Jersey: Pearson Prentice Hall

53. Hartono, Jogiyanto. 2011. Metodologi Penelitian Bisnis: Salah Kaprah dan Pengalaman-pengalaman. Yogyakarta: BPFE

54. Hasbullah, Jousairi. 2006. Social Capital (Menuju Keunggulan Budaya Manusia Indonesia). Jakarta: MR United Press.

55. Hatch, E., \& Farhady, H. 1981. Research Design \& Statistics for Applied Linguistics. Tehran: Rahnama Publications.

56. Inayah. 2012. Peranan Modal Sosial dalam Pembangunan, Ragam Jurnal Pembangunan Humaniora, Vol 12. No 1. April 2012

57. J. Gregory Dees. 1998. The Meaning of "Social Entrepreneurship". Stanford University.

58. Jhingan, M.L. 2000. Ekonomi Pembangunan dan Perencanaan. Jakarta: PT Raja Grafindo Persada

59. Jürgen G. Backhaus. 2003. Joseph Alois Schumpeter: Entrepreneurship, Style and Vision. Springer Science+. New York: Business Media

60. K. T. Windartini, dkk., 2014. Analisis Faktor-Faktor Yang Mempengaruhi Kredit Macet Pada Lembaga Perkreditan Desa (Lpd) Kecamatan Denpasar Timur. Periode 2010 sampai dengan 2012. e-Journal S1 Akuntansi Universitas Pendidikan Ganesha Jurusan Akuntansi S1 (Volume 2 No: 1 Tahun 2014).

61. Kane, Hillary., Ragsdell, Gillian., and Oppenheim, Charles. 2006. Knowledge Management Methodologies. Electronic Journal on Knowledge Management, vol 4, issue 2 (2006), p 141 - 152. Retrieved April 19, 2011, from www.ejkm.com.

62. Kanter, R.M. and Summers, D.V. 1987. Doing Well, While Doing Good: Dilemmas of Performance Measurement in Non-Profit Organizations and the Need for a MultiConstituency Approach. The Non-Profit Sector: A Research Handbook. W. W. Powell. Yale: Yale University Press

63. Keats, Barbara W. \& Hitt, Michael A. 1988. A Causal Model of Linkages Among Environmental Dimensions, Macro-Organizational Characteristics, and Performance, Academy of Management Journal, 31, 570-596

64. Kerlinger. 2006. Asas-Asas Penelitian Behavioral. Yogyakarta: Gadjah Mada University Press.

65. Laili, Nelly Nur. 2007. Analisis Faktor-Faktor yang Mempengaruhi Pertumbuhan Ekonomi DIY tahun 1990-2004, Skripsi, FE UII, tidak dipublikasikan, Yogyakarta.

66. Leksono, S. 2009. Runtuhnya Modal Sosial, Pasar Tradisional, Perspektif Emik Kualitatif. Malang: CV. Citra Malang

67. Lynn Barendsen and Howard Gardner. 2004. Is the social entrepreneur a new type of leader. Leader to Leader: Frances Hesselbein Leadership Forum. Volume 2004, Issue 34, Pages 43-50

68. Margono. 2010. Metodologi Penelitian Pendidikan. Jakarta: Rineka Cipta

69. Mort, G. S., Weerawardena, J. \& Carnegie, K. 2003. "Social entrepreneurship: Towards conceptualization", International Journal of Nonprofit \& Voluntary Sector Marketing, 8, 1, pp. 76.

70. Nelson, R.; Krashinsky, M, 1973. Two major issues of public policy: Public policy and organization of supply. In: R. Nelson \& D. Young (Eds), Public subsidy for day care of young children (pp. 47- 69). Lexington, MA: DC Heath \& Co. The new nonprofit almanac \& desk reference. (2002). San Francisco: Jossey-Bass.

71. Nelson, Richard and Michael Krashinky. 1973. "Two Major Issues of Policy: Public Subsidy and Organization of Supply," in Public Policy for Day Care of Young Children. D. Young and R. Nelson (Eds), Lexington, Mass: D.C. Heath, $9-21$

72. Nicholls, A. 2006. Playing the Field: A New Approach to the Meaning of Social Entrepreneurship. Social Enterprise Journal, 2.1, pp. 1-5

73. Norton, David, P., and Kaplan, Robert. S. 1992. The Balanced Scorecard - Measures that Drive Performance. Boston: Harvard Business Review, Reprint 92105 
74. Onyx, J,1996, "The Measure of Social Capital" paper presented to Australian and New Zealand Third Sector Research Conference on Social Cohesion, Justice and Citizenship: The Role of Voluntary Sector. Wellington: Victoria University

75. Penrose, Edith T. 1959. The Theory of the Growth of the Firm. Oxford: Blackwell

76. Peraturan Daerah Nomor 06 Tahun 1986 Tentang Kedudukan, Fungsi dan Peranan Desa Adat sebagai Kesatuan Masyarakat Hukum Adat dalam Propinsi daerah Tingkat I Bali

77. Peraturan Daerah Nomor 2 Tahun 1988 Tentang Lembaga Perkreditan Desa

78. Peraturan Daerah Nomor 3 Tahun 2001 Tentang Desa Pekraman

79. Peraturan Daerah Nomor 8 Tahun 2002 Tentang Lembaga Perkreditan Desa

80. Peraturan Daerah Nomor 3 Tahun 2003 tentang Lembaga Perkreditan Desa

81. Peraturan Daerah Nomor 12 Tahun 2003 tentang Prinsip Kehati-hatian dalam Mengelola Lembaga Perkreditan Desa (LPD) Bali.

82. Peraturan Daerah Nomor 4 tahun 2012 tentang Perubahan Kedua Atas Peraturan Daerah Provinsi Bali Nomor 8 Tahun 2002 Tentang Lembaga Perkreditan Desa

83. Peraturan Daerah Nomor 11 Tahun 2013 tentang Petunjuk Pelaksanaan Peraturan Daerah Provinsi Bali Nomor 8 Tahun 2002 tentang Lembaga Perkreditan Desa Peraturan Daerah Nomor 12 Tahun 2003 tentang Prinsip Kehati-hatian dalam Mengelola Lembaga Perkreditan Desa (LPD) Bali.

84. Peraturan Daerah Nomor 3 Tahun 2017 Tentang Lembaga Perkreditan Desa

85. Peraturan Daerah Nomor 44 Tahun 2017 Tentang Peraturan Pelaksanaan

86. Peraturan Daerah Provinsi Bali Nomor 3 Tahun 2017 Tentang Lembaga Perkreditan Desa

87. Putnam R D. 1993. "The Prosperous Community: Social Capital and Public Life, The American of Prospect, Vol 13, pp 35-42

88. Rasmen Adi, I Nyoman, dkk. 2017. The Role of Government in Community Based Tourism and Sustainable Tourism Development at Penglipuran Traditional Village Bali. IOSR Journal of Humanities and Social Science (IOSR-JHSS) Volume 22, Issue 6, Ver.13 (June. 2017) PP 15-20:SEPPe-ISSN: 2279-0837, p-ISSN: 2279-0845. www.iosrjournals.org

89. Reis, Tom. 1999. Unleashing the New Resources and Entrepreneurship for the Common Good: A Scan, Synthesis and Scenario for Action. Battle Creek, MI: W.K. Kellogg Foundation. pp 27

90. Riawan, Tjandra dkk. 2005. Peningkatan Kapasitas Pemerintah Daerah Dalam Pelayanan Publik. Yogyakarta: PT. Pembaharuan

91. Santoso, Singgih. 2005. Menguasai Statistik di Era Informasi Dengan SPSS 12. Jakarta: PT. Elex Media Komputindo

92. Sarah H. Alvord, L. David Brown, Christine W. Letts,. 2004. Social Entrepreneurship and Societal Transformation, An Exploratory Study. First Published

93. Schumpeter, Joseph. 1951. "Change and the Entrepreneur" in Essays of J.A.

94. Sekaran, Uma. 2003. Metodologi Penelitian Untuk Bisnis. Jakarta: Salemba Empat

95. 2009. Research Methods for Business: Metodologi Penelitian untuk Bisnis. Edisi 4. Buku 1. Jakarta: Salemba Empat

96. Solimun, MS. 2004. Pemodelan Statistika: Structural Equal Modelling (SEM) Aplikasi Amos. Pekanbaru: Diklatpada Universitas.

97. Sugiyono. 2001. Metode Penelitian Administrasi. Bandung: CV. Alfabeta

98. 2009. Metode Penelitian Kuantitatif, Kualitatif dan R\&D. Bandung: CV. Alfabeta.

99. 2011. Metode penelitian Kombinasi (Mix Methods). Bandung: CV. Alfabeta

100. Suharto. 2007. Pekerjaan Sosial di Dunia Industri: Memperkuat Tanggungjawab Sosial Perusahaan (Corporate Social Responsibily)". Bandung: Refika Aditama.

101. Sukirno, S. 2006. Pengantar Bisnis. Jakarta: Penerbit Kencana

102. Sumarni. 2013. Intervensi Pemerintah, Antara Kebutuhan Dan Penolakan Di Bidang Ekonomi. ECONOMICA. Journal of Economic and Economic Education Vol.1 No.2 $(183-194)$ 
103. Tan, Wee-Ling., Williams, John., dan Tan, Teck-Meng. (2005). 'Defining the 'Sosial' in 'Sosial Entrepreneurship': Altruism and Entrepreneurship'. International Entrepreneurship and Management Journal 1, pp 353-365

104. Thoha, Miftah. 2002. Perilaku Organisasi. Jakarta: Raja Grafindo Persada

105. Thompson, L. John. 2002. The World of the Social Entrepreneur. International Jurnal of Public Sector Management, Vol. 15 Issue: 5, pp. 412-431.

106. Undang-Undang Republik Indonesia Nomor 1 Tahun 2013 Tentang Lembaga Keuangan Mikro

107. Weisbrod, B. A. 1977. The Voluntary Nonprofit Sector: An Economic Analysis. Lexington, MA: Lexington Books.

108. Wellman, Barry and Berkowitz, S.D. (eds.), 1988/1997. Social Structure: A Network Approach. Greenwich, Conn. JAI Press

109. Wiklund Johan. 1999. The Sustainability of the Entrepreneurial OrientationPerformance Relationship, Entrepreneurship Theory and Practice, Baylor University.

110. Woolcock, M. 1998. Social Capital and Economic Development: Toward o Theoretical Synthesis and Policy Framework. Theory and Society, 27 (2): 151 - 208.

111. Zadek, Simon and Stephen, Thake. 1997. "Send in the Social Entrepreneurs" in New Statesman, June 20, Vol. 26, Issue 7339, P. 31

112. Zulganef. 2006. Pemodelan Persamaan Struktur dan Aplikasinya menggunakan AMOS 5. Bandung: Pustaka 